\title{
Application of Scharer's quantitative method for the determination of residual alkaline phosphatase activity in standard Minas cheese
}

\author{
[Aplicação do método modificado de Scharer para a determinação quantitativa da atividade de \\ fosfatase alcalina residual em queijo minas padrão] \\ C.F. Soares ${ }^{1}$, L.M. Fonseca ${ }^{2 *}$, M.O. Leite ${ }^{2}$, M.C.P.P. Oliveira ${ }^{1}$ \\ ${ }^{1}$ Aluno de pós-graduação - Escola de Veterinária - Universidade Federal de Minas Gerais - Belo Horizonte, MG \\ ${ }^{2}$ Escola de Veterinária - Universidade Federal de Minas Gerais - Belo Horizonte, MG
}

\begin{abstract}
Milk pasteurization is a critical issue in the dairy industry, and failures in this process can affect final product safety. Scharer's enzymatic method is still traditionally used to verify pasteurization efficiency compliance, and it is based on screening for residual alkaline phosphatase in milk. Although several methods are used to quantify enzymatic activity to assess milk pasteurization efficiency, there is a small amount of published data regarding the use of these methods to quantify alkaline phosphatase in cheese. In this study, the Scharer's modified method was used to determine the levels of residual alkaline phosphatase in standard minas cheese, before and after 20 days of ripening. The cheeses were made using raw or pasteurized milk with the addition of different concentrations of raw milk $(0 ; 0.05 \% ; 0.10 \%$; $0.20 \%$; and $0.50 \%$ ). In the fresh cheese samples, the method showed a sensitivity of only $0.50 \%$ with the addition of raw milk to the pasteurized milk used to make cheese. In addition, levels of up $0.20 \%$ of raw milk in pasteurized milk, the concentrations of phenol was inferior to $1 \mu \mathrm{g}$ phenol/g of dairy product which is the preconized indicator value for adequate pasteurization.
\end{abstract}

Keywords: alkaline phosphatase, standard Minas cheese, Scharer's modified method, spectrophotometry

\section{RESUMO}

A pasteurização do leite é um ponto crítico na indústria de laticínios, e falhas nessa etapa comprometem a segurança do produto. O método enzimático de Scharer é tradicionalmente utilizado na verificação da eficiência da pasteurização e baseia-se na pesquisa da atividade de fosfatase alcalina residual em leite. Embora vários métodos estejam disponíveis para avaliar a eficiência da pasteurização, há um número reduzido de dados publicados baseados na quantificação da atividade da fosfatase alcalina em queijo. Neste estudo, o método modificado de Scharer foi utilizado para determinar os níveis de fosfatase alcalina residual em queijo minas padrão, antes e após 20 dias de maturação. Os queijos foram feitos com leite cru ou com leite pasteurizado com adição de diferentes concentrações de leite cru (0, 0,05\%, 0,10\%, 0,20\% e 0,50\%). Nas amostras de queijo fresco, o método apresentou sensibilidade apenas com 0,50\% de adição de leite cru ao leite pasteurizado utilizado na fabricação de queijo. Em níveis de adição de até $0,20 \%$ de leite cru no leite pasteurizado, as concentrações de fenol se mostraram inferiores a $1 \mu \mathrm{g}$ de fenol/g de produto lácteo, que é o valor preconizado como indicador de pasteurização adequada.

Palavras-chave: fosfatase alcalina, queijo minas padrão, método modificado de Scharer, espectrofotometria

Recebido em 4 de março de 2012

Aceito em 6 de março de 2013

*Autor para correspondência (corresponding author)

E-mail: leorges@ufmg.br 


\section{INTRODUCTION}

Cheeses produced with raw milk may present a threat to public health, mainly due to the possibility of disease outbreaks (Zottola and Smith, 1993). In some countries, cheese may be manufactured with raw milk, since a 60-day ripening time is observed before consumption. This would be the minimum required time to inactivate pathogenic microorganisms by physicochemical modifications (Kleyn and Goodman, 1977; Abedini et al., 2007). However, the vast majority of the cheeses worldwide are produced with pasteurized milk, since milk pasteurization is the safest process to minimize risk of food borne diseases, as it eliminates pathogenic microorganisms without significant sensorial and physicochemical modifications. To guarantee safety, it is important to verify compliance with pasteurization conditions using qualitative and quantitative methods, among them, the determination of alkaline phosphatase (ALP) activity.

Alkaline phosphatase (EC 3.1.3.1) is a membrane-bound glycoprotein with sialic acid as sugar moiety. It is a phospho-monoesterase enzyme which catalyzes the hydrolysis of monoesters of phosphoric acid (at alkaline $\mathrm{pH}$ ), yielding phosphate and the corresponding alcohol. The abundance in nature and importance of this enzyme in biological systems has made ALP activity assessments one of the most commonly performed enzymatic tests (Miggiano et al., 1983; Rankin et al., 2010).

Pasteurization conditions are designed to effectively destroy the Mycobacterium tuberculosis and Coxiella burnetii (Cerf and Condron, 2006) organisms. As the enzyme alkaline phosphatase is inactivated in temperature ranges slightly higher than these microorganisms, it is used as an indicator for monitoring good pasteurization conditions (Sanders and Sager, 1948; Murthy and Cox, 1988; Holsinger et al., 1997; Stabel, 2003). Other interpretations of elevated ALP activities in finished products include the presence of bacterial ALP, or the biochemical reactivation of the ALP enzyme (Rankin et al., 2010).

Scharer's modified method is one of the classic methods for the determination of ALP activity in dairy products, and its sensitivity is supposed to detect levels such as $0.1 \%$ of raw milk contamination in the pasteurized milk. Low residual levels of ALP in dairy products ensure that the milk was submitted to an appropriate pasteurization process, unless there is a post-pasteurization contamination with raw milk (Murthy et al., 1992). In the modified method, ALP enzymatically cleaves a phosphate group from added disodium phenyl phosphate substrate. The released phenol group is reacted with 2.6-dichloroquinone-chlorimide, instead of the traditional 2.6-dibromoquinone-4chloroimide. 2.6-dichloroquinone-chlorimide is more stable than the 2.6-dibromoquinone-4chloroimide. After reaction, the blue color compound indophenol is formed. Under the controlled conditions of this assay increased ALP activity in the milk will generate an increasingly intense blue color. The intensity of the blue is compared visually against a set of standards or read with a spectrophotometer (Rankin et al., 2010).

Although quantification of residual levels of ALP is an important method to determine safety status of dairy products, there is no available information for its application in standard minas cheese, an important typical Brazilian cheese. Since different technological steps and composition are factors that may determine different residual levels for this enzyme, data collected in other types of cheese might result in mistaken interpretation of safety levels. Moreover, residual levels of enzyme are related to thermal process and initial enzyme levels. These factors may affect the detection limits for this enzyme ( Harding, 1991, Yoshotomi, 2004; Harding and Garry, 2005).

Standard Minas cheese is obtained from whole or standardized milk, pasteurized, and mechanically pressed, with twenty days of ripening (Brazil, 1952). This cheese differs from minas frescal cheese, a fresh cheese. Standard Minas cheese is dry, firm, with a thin and yellow skin, and a white creamy color inside, with irregular eyes, and slight flavor, with low acidity (Furtado and Lourenço Neto, 1994).

The objective of this study was to evaluate Scharer's modified method (spectrophotometric) for alkaline phosphatase measurement in standard Minas cheese manufactured with raw 
milk and pasteurized milk added with raw milk at different proportions.

\section{MATERIALS AND METHODS}

Raw bulk tank milk was pasteurized at $65^{\circ} \mathrm{C}$ for 30 minutes and inoculated with Visbyvac ${ }^{\circledR}$ DVS mesophilic culture (Lactococcus lactis ssp. lactis and Lactococcus lactis ssp. cremoris). Additional ingredients included calcium chloride $(20 \mathrm{~g} / 100$ liters of milk) and liquid rennet, with coagulant strength of 1:3000 (Ha-la ${ }^{\circledR} ; 1 \mathrm{~mL} / 10 \mathrm{~L}$ of milk).

Standard Minas cheese manufacturing followed procedure according to Figure 1. The following treatment structure was applied: treatment 1 (cheese made with pasteurized milk); treatment 2, 3, 4, and 5, cheese made from pasteurized milk, added of raw milk at concentrations of, respectively, $0.05 \%, 0.10 \%, 0.20 \%$, and $0.50 \%$; and treatment 6 (cheese made with raw milk).

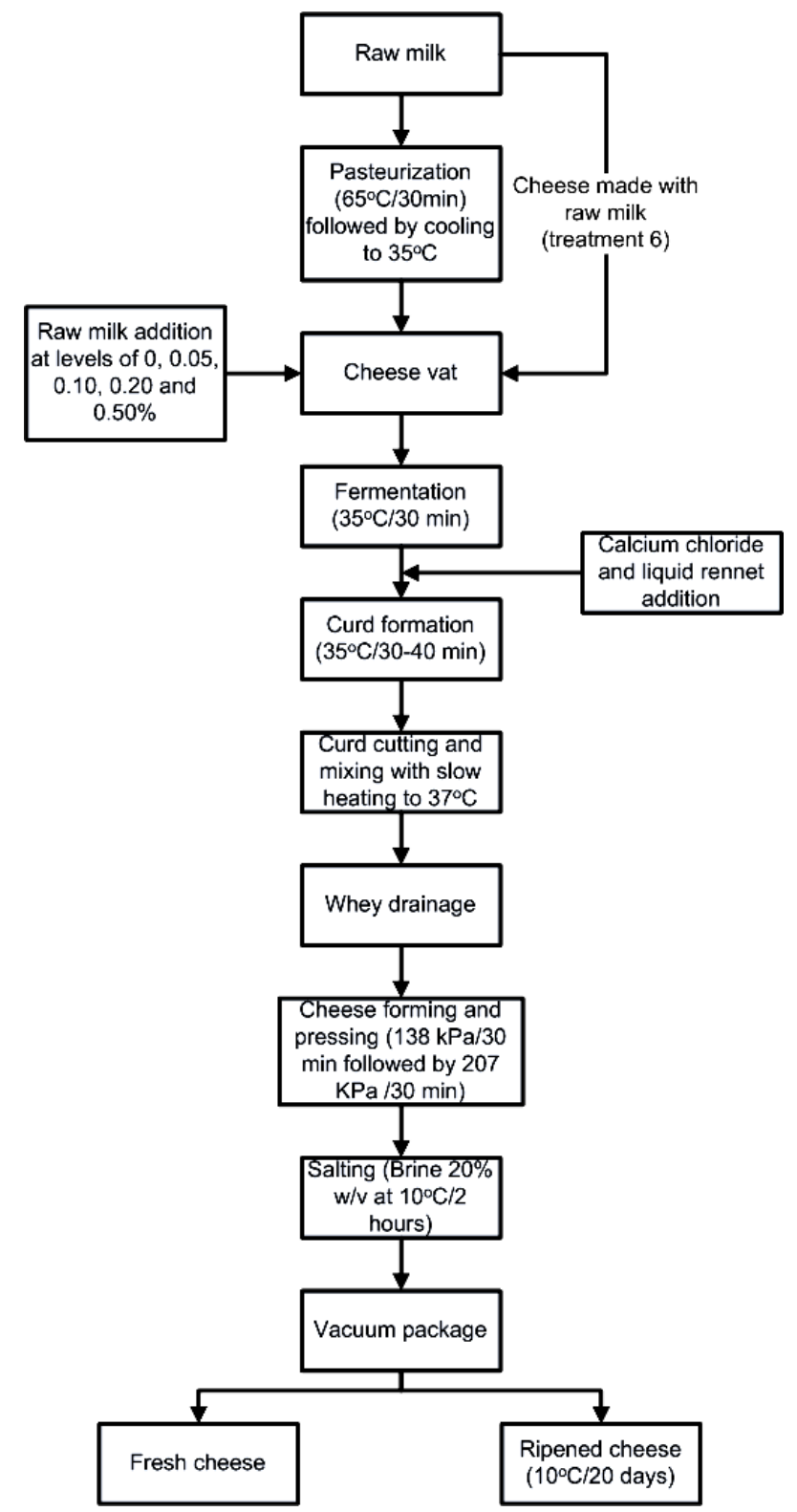

Figure 1. Flowchart for standard minas cheese manufacture 
The cheeses were manufactured in a laboratory pilot scale, using four liters of milk for each batch, in each treatment, with the final production of two cheeses with approximately $200 \mathrm{~g}$ for each batch. Each treatment was repeated four times with milk from different origins. For each batch, one cheese was analyzed, and the others were kept under refrigerated storage $\left(10^{\circ} \mathrm{C} \pm 1^{\circ} \mathrm{C}\right)$ for 20 days with environmental humidity monitoring inside the cooler. Additional research of alkaline phosphatase activity in the samples of raw and pasteurized milk used in cheese production was done to assess pasteurization compliance (Brazil, 1981).

Cheese ALP was measured by Scharer modified method (Murthy et al., 1992). A $5 \mathrm{~g}$ aliquot of cheese was ground with $2 \mathrm{~mL}$ buffered carbonate. The enzyme extraction was done with addition of $18 \mathrm{~mL}$ of butanol $(8.3 \% \mathrm{v} / \mathrm{v}$ in distilled water), followed by agitation in vortex, and filtration. One $\mathrm{mL}$ of the filtered was mixed to $0.2 \mathrm{~mL}$ of magnesium acetate solution $(1 \mathrm{~g} / 100 \mathrm{~mL})$, and $0.5 \mathrm{~mL}$ of the mixture was added to $5 \mathrm{~mL}$ of disodium phenyl phosphate buffer substrate, followed by incubation in a water bath $\left(40^{\circ} \mathrm{C} / 15 \mathrm{~min}\right)$. After incubation, 2 drops of copper sulfate solution, and $0.1 \mathrm{~mL}$ of CQC reagent $\left(\right.$ Sigma $\left.^{\circledR}\right)$ were added, followed by further incubation for 5 minutes. The solution was cooled in ice and the produced indophenol was extracted with $3 \mathrm{~mL}$ of neutralized butanol. The Phenol concentration in the sample was determined by spectrophotometry at $655 \mathrm{~nm}$ (Microplate Reader 3350; BIO-RAD ${ }^{\circledR}$ ) (Fig. 2).
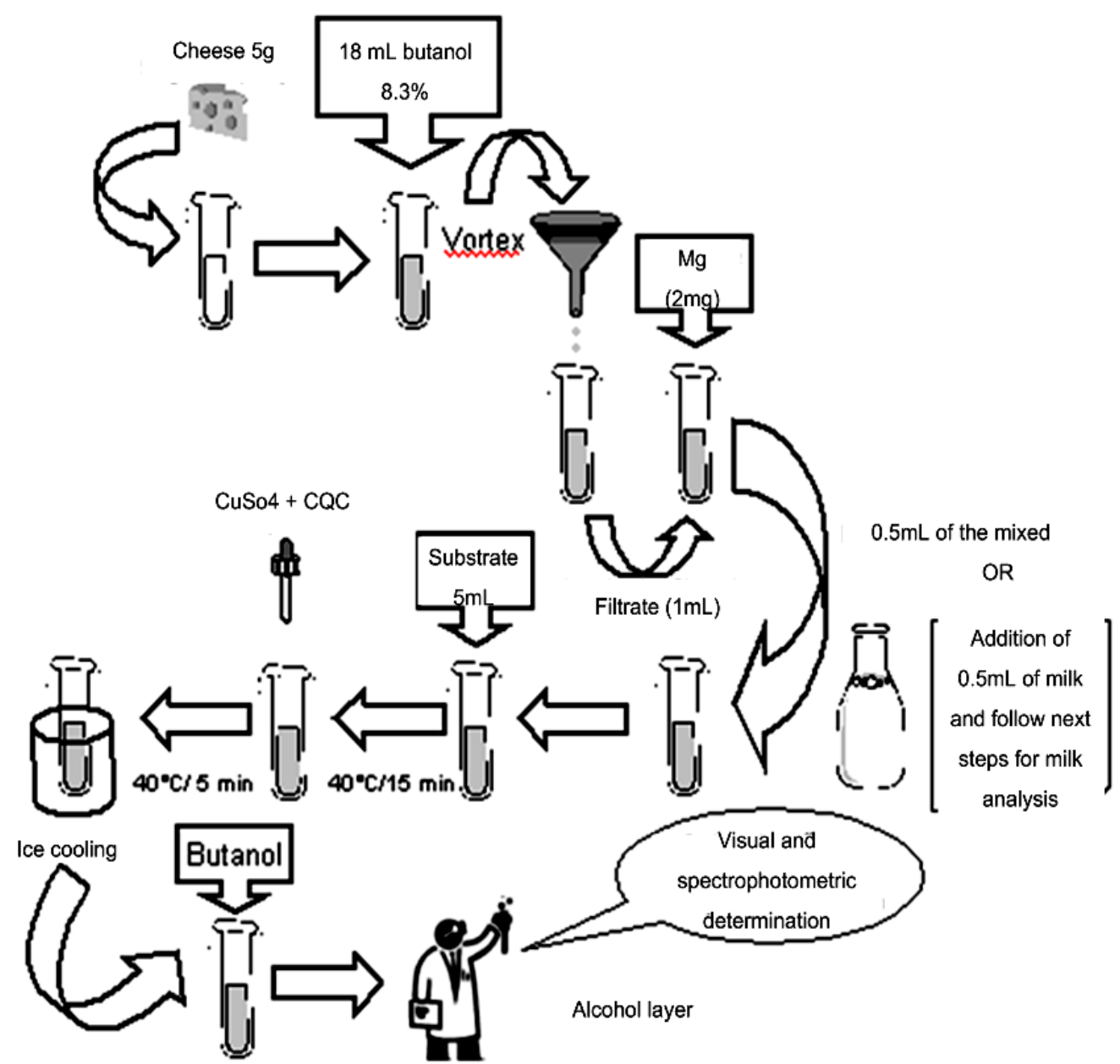

Figure 2. Scheme to determine alkaline phosphatase activity in samples of cheese by the Scharer modified method. 
Values above $1 \mu \mathrm{g} / \mathrm{g}$ of phenol in cheese were considered indicative of raw milk contamination. The calibration curve was obtained using phenol solutions in water $(0 ; 1.0 ; 2.0 ; 5.0$; and $10.0 \mu \mathrm{g}$ of phenol equivalent $/ \mathrm{mL}$ ). Because of the intense blue color of the cheese produced with raw milk, the filter was diluted (1:50) in a buffer without substrate (Kosikowsky, 1951).

Negative and positive controls for ALP were prepared and tested in each batch of cheese production, as well as control for differentiation of microbial ALP and interfering substances, according to Murthy et al. (1992).

Treatment 6 (cheese manufactured with raw milk) was excluded from pairwise comparison among treatments, since the phenol concentration was much higher when compared to the other treatments. The statistical analysis included the five treatments remaining in a factorial arrangement of five treatments with two ripening times, with four experimental runs. Results were submitted to Analysis of Variance and the means compared by Dunnett's test at 5\% significance $\left(\right.$ Minitab $\left.^{\circledR} 15\right)$.

\section{RESULTS AND DISCUSSION}

For all the batches in the experiment, alkaline phosphatase activity was detected in the raw milk used for cheese making, and was inactivated after pasteurization. In the cheeses manufactured with raw milk, enzyme analysis was done after sample dilution with distilled water, since the amount of produced phenol was higher than the range of the calibration curve.

Results of enzymatic activity for ALP in the experimental samples of standard Minas cheese are in Table 1. For cheeses made with raw milk, this is an approximate value, due to needed dilution for spectrophotometric reading, and the standard deviation was not determined.

Table 1. Alkaline phosphatase activity in fresh and aged standard Minas cheese, manufactured from raw milk or pasteurized milk added with different amounts of raw milk

\begin{tabular}{|c|c|c|}
\hline \multirow{3}{*}{ Milk used for cheese production } & \multicolumn{2}{|c|}{ Cheese ripening time (days) } \\
\hline & Fresh ( $\left(1^{\text {st }}\right.$ day) & Aged (20 days) \\
\hline & $\mathrm{AF}^{*}$ & $\mathrm{AF}^{*}$ \\
\hline Pasteurized milk & $0.225 \pm 0.096 \mathrm{cA}$ & $0.900 \pm 0.424$ bB \\
\hline Pasteurized $+0.05 \%$ raw milk & $0.500 \pm 0.141 \quad \mathrm{bcA}$ & $0.900 \pm 0.424$ bA \\
\hline Pasteurized $+0.10 \%$ raw milk & $0.600 \pm 0.141 \mathrm{bcA}$ & $1.075 \pm 0.359 \mathrm{bA}$ \\
\hline Pasteurized $+0.20 \%$ raw milk & $0.900 \pm 0.163 \mathrm{bA}$ & $1.475 \pm 0.275 \mathrm{bB}$ \\
\hline Raw Milk & 140,000 & 202,500 \\
\hline
\end{tabular}

$(*) \mathrm{AF}=$ alkaline phosphatase activity ( $\mu \mathrm{g}$ of phenol $/ \mathrm{g}$ of cheese $/ 15$ minutes of incubation)

${ }^{a}$ Different lower case letters in the same column indicate different values $(\mathrm{P}<0.05)$

${ }^{\text {A }}$ Different capital letters in the same line indicate different values $(\mathrm{P}<0.05)$

ALP activity was detected at levels higher than $1 \mu \mathrm{g}$ of $\mathrm{phenol} / \mathrm{g}$ of cheese for cheese made with raw milk addition at levels of $0.50 \%$ to the pasteurized milk, regardless of the time of manufacture, i.e., fresh or 20 days of ripening. However, for treatments with raw milk addition at levels of $0.10 \%$, and $0.20 \%$ to the pasteurized milk, ALP levels were higher than $1 \mu \mathrm{g}$ de fenol/g only for the aged cheese (20 days), with significant differences for the cheese made with pasteurized milk added with $0.20 \%$ of raw milk $(\mathrm{p}<0.05)$. This indicates reactivation of ALP enzyme during the ripening period, with important implications when final levels are above $1 \mu \mathrm{g} \mathrm{fenol/g}$ of cheese. It is important to note that a safety risk remains at detection limits for ALP of $1 \mu \mathrm{g}$ of phenol/g of cheese, since levels of raw milk contamination as high as $0.20 \%$ or $0.10 \%$ in pasteurized milk may not be detected in fresh cheeses.

ALP levels in cheese is a well known safety issue in the dairy industry, since its measurement through classical methods, such as the Scharer's, might indicate an incorrect pasteurization process when significant levels of raw milk contamination are present or even after pasteurization, with risk for consumers (Painter, 1995; Painter and Bradley Jr., 1997; Angelino et al., 1999). The present work confirms these findings for standard Minas cheese. However, 
detection levels were above $0.10 \%$ of raw milk contamination in the milk.

After 20 days of ripening, average amounts of residual ALP in cheese made with pasteurized milk added of $0.10 \%$ and $0.20 \%$ of raw milk were above the equivalent level of $1 \mu \mathrm{g}$ of $\mathrm{phenol} / \mathrm{g}$ of cheese. This is an international limit recognized as safe for residual activity of ALP. However for this level of raw milk contamination, ALP was below $1 \mu \mathrm{g}$ of phenol/g of fresh cheese. Similarly, Kosikowsky (1951, 1964) demonstrated risk of underestimated safety risk, since levels of $0.10 \%$ and $0.30 \%$ of raw milk contamination in pasteurized milk were not detected in the Cornell and dialysis method, even with delayed incubation time.

Murthy and Cox (1988) evaluated the Sharer colorimetric method as an efficient test to determine residual ALP in cheese. However, the method used by these authors differed from the present experiment, since raw milk added to cheese was used, instead of mixing it with pasteurized milk that would be used for the cheese manufacture.

Figure 3 shows the occurrence in ALP reactivation after ripening time in some of the treatments $(\mathrm{P}<0.05)$. This fact emphasizes the need for detection of ALP residual levels in fresh cheese, since the increase in this enzyme activity may occur during the ripening due to reactivation of the enzyme or microbial production (contaminant or lactic). For the present experiment, the control for microbial alkaline phosphatase activity was done for all the runs, showing that the increase in enzyme activity after cheese ripening was not due to microbial production (Murthy and Cox, 1988; Rosenthal et al., 1996).
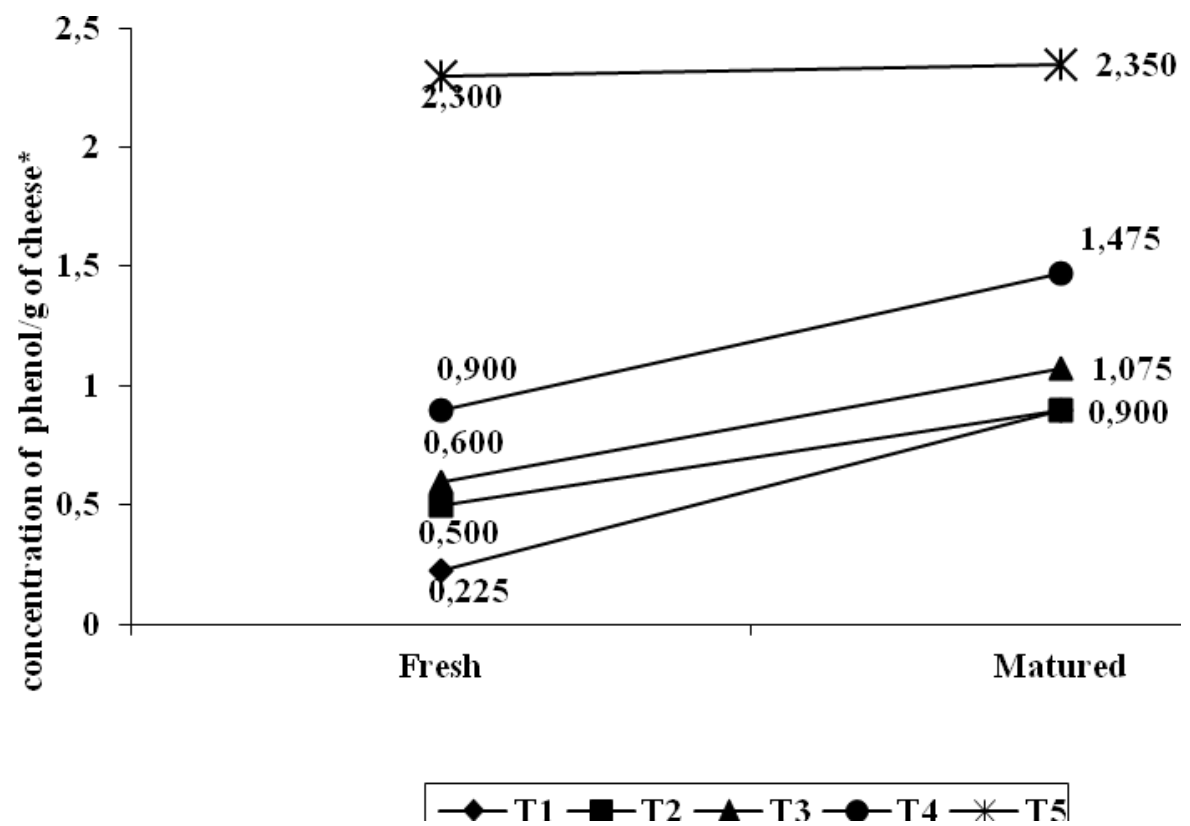

* $\mu \mathrm{g}$ of $\mathrm{phenol} / \mathrm{g}$ of cheese/15 minutes in incubation

Figure 3. Effect of ripening time on the concentration of phenol in samples of standard Minas cheese produced from pasteurized milk added with different amounts of raw milk.

During the development of this work, Scharer's modified method presented some drawbacks, such as phenol contamination risk, unstable reagents, and emulsification during the extraction step as previously noted by other authors
(Babson and Greeley, 1967; Kleyn and Lin, 1968). Additionally, since the standard curve is made with diluted solutions of phenol in water, milk components may affect color during spectrophotometric reading. 


\section{CONCLUSIONS}

The Scharer modified method for spectrophotometric quantification of residual enzymatic activity of ALP is efficient in detecting levels of this enzyme in cheese, equivalent to levels higher than $0.50 \%$ of raw milk contamination in pasteurized milk. The equivalent value of $1 \mu \mathrm{g}$ of phenol/g of dairy product is considered high to be used as indicator of efficient pasteurization, since significant contamination levels of raw milk to the pasteurized milk may result in lower phenol equivalent values. Cheese ripening may have resulted in enzyme activity increase due to ALP reactivation.

\section{ACKNOWLEDGEMENTS}

CNPq (projeto 578736/2008-0), FAPEMIG.

\section{REFERENCES}

ABEDINI, F.; FOROUTAN, T.; JAHANGIRI, L. Alkaline phosphatase and CD34 reaction of deciduous teeth pulp stem cells. Pak. J. Biol. Sci., v.10, p.31463149, 2007.

ANGELINO, P.D.; CHRISTEN, G.L.; PENFIELD, M.P. et al. Residual alkaline phosphatase activity in pasteurized milk heated at various temperaturesmeasurement with the Fluorophos and Scharer rapid phosphatase tests. J. Food Prot., v.62, p.81-85, 1999.

BABSON, A.L.; GREELEY, S.J. New substrate for alkaline phosphatase in milk. J. Assoc. Off. Anal. Chem., v.50, p.555-557, 1967.

BLACK, R.G.; KUZYK, M.; DUGGAN, J. Evaluation of a fluorometric assay for alkaline phosphatase in fluid dairy products. Aust. J. Dairy Technol., v.47, p.64-67, 1992.

BRASIL. Ministério da Agricultura e do Abastecimento. Secretaria de Defesa Agropecuária. Departamento de Inspeção de Produtos de Origem Animal - DIPOA. Divisão de Normas Técnicas. Regulamentos da Inspeção Industrial e Sanitária de Origem Animal. Brasília: Ministério da Agricultura, 1952.

BRASIL. Ministério da Agricultura e do Abastecimento. Secretaria Nacional de Defesa Agropecuária. Laboratório Nacional de Referência Animal - LANARA. Métodos analíticos oficiais para $o$ controle de produtos de origem animal e seus ingredientes.II Métodos físico-químicos. Brasília, 1981.
CERF, O.; CONDRON, R. Coxiella burnetii and milk pasteurization: an early application of the precautionary principle? Epidemiol. Infect., v.134, p.946-951, 2006.

FURTADO, M.M.; LOURENÇO NETO, J.P.M.. Tecnologia de queijos: manual técnico para a produção industrial de queijos. São Paulo: Dipemar, 1994. 118p.

HARDING, F. Alkaline phosphatase test as a measure of correct pasteurization. Bulletin of the IDF, n. 262, p.32-34, 1991.

HARDING, F.; GARRY, E. Collaborative evaluation of a fluorometric method for measuring alkaline phosphatase activity in cow's, sheep's, and goat's milk. J. Food Prot., v.68, p.1047-1053, 2005.

HOLSINGER, V.H.; RAJKOWSKI, K.T.; STABEL, J.R. Milk pasteurization and safety: a brief history and update. Rev. Sci. Tech. Off. Int. Epiz., v.16, p.441-451, 1997.

KLEYN, D.H.; LIN, S.H.C. Collaborative study of a new alkaline phosphatase assay system for milk. $J$. Assoc. Off. Anal. Chem., v.51, p.802-807, 1968.

KLEYN, D.H.; GOODMAN, S.T. Rapid determination of alkaline phosphatase activity in cheese. J. Assoc. Off. Anal. Chem. v.60, p.1397-1399, 1977.

KOSIKOWSKY, F.V. The effectiveness of the Cornell phosphatase test for dairy products. J. Dairy Sci., v.34, p.1151-1158, 1951.

KOSIKOWSKY, F.V. Dialysis phosphatase method for milk and all dairy products. J. Dairy Sci., v.47, p.748-753, 1964.

MIGGIANO, G.A.; MORDENTE, A.; MARTORANA, G.E. et al. In vitro effect of ascorbic acid on bovine kidney alkaline phosphatase activity. Acta Vitaminol. Enzymol., v.5, p.153-158, 1983.

MURTHY, G.K.; COX, S. Evaluation of APHA and AOAC methods for phosphatase in cheese. J. Assoc. Off. Anal. Chem., v.71, p.1195-1199, 1988.

MURTHY, G.K.; KLEYN, D. H.; RICHARDSON, T. et al. Alkaline phosphatase methods. In: MARSHALL, R.T. (Ed.). Standard methods for the examination of dairy products. 16 ed. Washington: APHA, 1992. p.413-431.

PAINTER, C.J. Residual alkaline phosphatase activity in milks subjected to various time/temperature treatments. 1995. 119f. Thesis (Master of Science) University of Wisconsin, Madison.

PAINTER, C.J.; BRADLEY JR, L. Residual alkaline phosphatase activity in milks subjected to various time-temperature treatments. J. Food Prot., v.60, p.525-530, 1997. 
RANKIN, S.A.; CHRISTIANSEN, A.; LEE, W. et al. Invited review: The application of alkaline phosphatase assays for the validation of milk product pasteurization. J. Dairy Sci., v.93, p.5538-5551, 2010.

ROSENTHAL, I.; BERNSTEIN, S.; ROSEN, B. Alkaline phosphatase activity in Penicillium roquefort and blue-veined cheeses. J. Dairy Sci., v.79, p.16-19, 1996.

SANDERS, G.P.; SAGER, O.S. Heat inactivation milk phosphatase in dairy products. J. Dairy Sci., v.31, p.845-857, 1948.
STABEL, J.R. Effective methods for postharvest intervention in dairy processing. J. Dairy Sci., v.86, p.10-15, 2003

YOSHITOMI, K. Alkaline phosphatase activity in cheeses measured by fluorometry. Int. J. Food Sci. Technol., v.39, p.349-353, 2004

ZOTTOLA, E.A.; SMITH, L.B. Growth and survival of undesirable bacteria in cheese. In: FOX, P.F. (Ed.). Cheese chemistry, physics and microbiology. 2.ed. London: Chapman \& Hall, 1993. v.1, p.471-492. 